\title{
Amelia Bloomer: An Early Iowa Feminist's Sojourn On The Way West
}

\author{
Lorle Ann Porter
}

THE AMERICAN WEST WAS the place where new lives began, where ideas flourished, where the evils of the past might be avoided. To idealists, the empty vastness of the trans-Mississippian West was a pristine laboratory open for experimentation: the hopeful site for the fulfillment of ageless dreams. Religious and communal societies such as Shakers, Owenites, Zoarites, Moravians and Mormons speckled "the West," from Ohio westward, and bore witness to the "new life" thought possible there.

Little wonder then, that, in the tumultuous years of reform prior to the Civil War, restless reformers, many of them cast in the mold of evangelists, continued to move westward. The new territories, they avowed, were not to be sullied by slavery, by alcohol, nor by the trusts. Iowa, Nebraska, Minnesota embraced a swarm of settlers in the 1850s. Along with the normal flow of immigrants, bankrupt farmers caught in panics, lawyers seeking fortunes in land, railroad builders, and others, came reformers, notably "Beechers Bibles"1 and the legendary temperance and woman's rights advocate Mrs. Amelia Jenks Bloomer.

\footnotetext{
1"Beechers Bibles" was a term applied to rifles purchased during the Kansas Nebraska troubles of 1854-56. Funds were raised throughout the East to permit the massive emigration of free soilers into the disputed territories, hopefully to secure a free-state majority. At one meeting, Henry Ward Beecher argued that Sharp's Rifles in the hands of emigrants would be a better deterrent to slave holders than Bibles. Funds were solicited for the purchase of the rifles at several subsequent meetings. Dictionary of American History, Vol. 1, 173. James Truslow Adams, Editor. New York, 1940.
} 


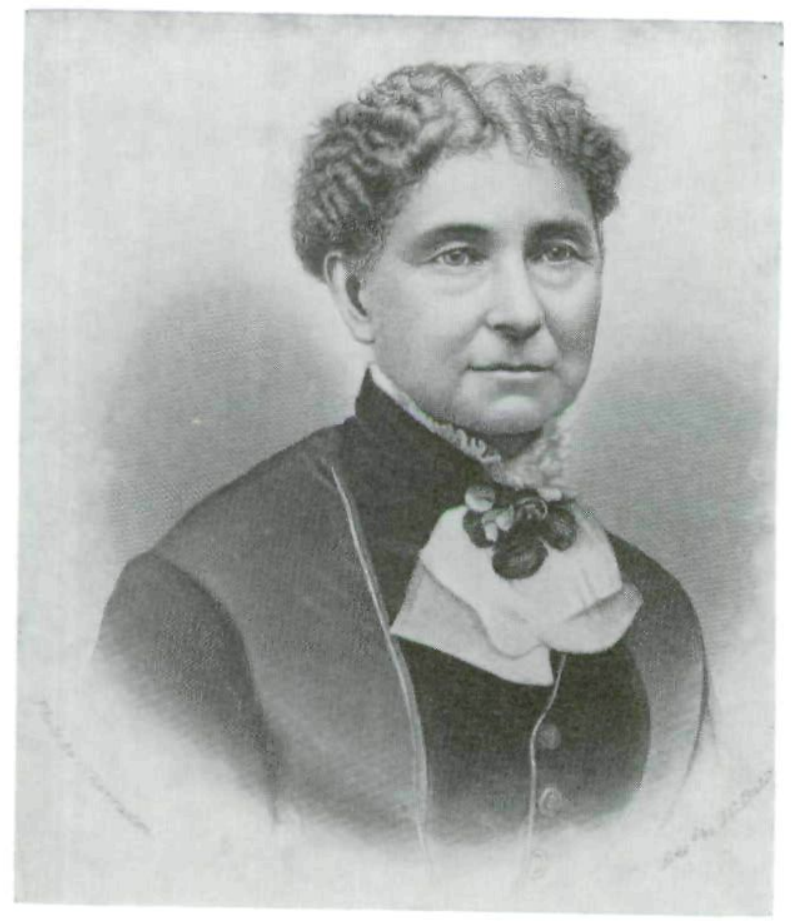

Department of History and Archives

Amelia Bloomer

Westward movement progressed in various stages, as the trails of family homesteads across several states will attest. Mrs. Bloomer's trail west, from Seneca Falls, New York to Council Bluffs, Iowa, was broken by an hiatus of a year and five days in Mt. Vernon, Ohio. During that year her attempt to employ women in her newspaper office led to a printers' strike, considered by her husband to be one of the apexes of her career in the woman's rights movement. Recent intensive research into Mt. Vernon politics sheds light on this vague period of her life in Ohio.

Dexter C. Bloomer, like many newspapermen of his era, moved frequently. His wife went with him. Amelia's lecture trips apparently served to assess the areas into which he planned to move. On his western trip in October of 1853, Mrs. Bloomer attended the National Woman's Rights Convention in 
Cleveland, then continued on to deliver lectures in Detroit, Chicago and Milwaukee. From Cleveland, however, she made a journey to Columbus, passing on the railroad through two growing central Ohio towns, Mt. Vernon, and its larger rival Newark, thirty miles south. She spoke in the former on the Maine Law (the proposed Ohio Temperance law), but was chagrined at the spectacle of hard drinking in Newark, a factor which might have persuaded she and Dexter to settle in the less rowdy Mt. Vernon. She found the town to be "a pleasant village of about 6,000 inhabitants" which supported four newspapers, "among them the Western Home Visitor, which is a reformatory paper of high character and has a circulation of about four thousand copies." Shortly thereafter, Bloomer purchased part ownership of the Western Home Visitor, a Temperance organ. Mrs. Bloomer resigned as corresponding secretary of the Woman's New York State Temperance Society, and in December the couple prepared for the move to "our new home 'at the West'." The Western Home Visitor was a literary-reform folio, without advertising, which sought a national constituency, as did Mrs. Bloomer's own paper, "The Lily. ${ }^{2}$ Both apparently increased circulation during this year, The Lily achieving a circulation of six thousand copies. The Western Home Visitor has been lost, but its national character is revealed in The Lily. Proud of being, to her knowledge, the first woman to edit and publish a paper, Amelia assumed the additional responsibility of assistant editor of the Western Home Visitor, and wrote an average of one article per issue

${ }^{2}$ Dexter C. Bloomer, The Life and Writings of Amelia Bloomer (Boston: Arena Publishing Company, 1895), 138. The Lily, January 2, 1854. The Lily was a Temperance-Woman's Rights bi-monthly founded by Amelia Jenks Bloomer in Seneca Falls, New York in 1849. It was edited and published by Mrs. Bloomer on the press of her husband's newspapers. The title on the masthead read "The Lily. Devoted to the interests of Women: suffrage, legal rights of women, Temperance." Elizabeth Cady Stanton wrote frequently for The Lily under the psuedonem "Sunflower." Other contributors, such as Susan B. Anthony and Antoinette Brown, made The Lily the most influential journal arguing for woman's reforms of its age. Mrs. Bloomer had control of the paper until its sale in 1854. Portions of The Lily are on file at the New York State Library, Harvard University Library and the Boston Public Library. A microfilm copy was kindly lent to the author by the University of Pennsylvania. 
for this journal, on her favorite topics of Temperance, woman's rights and the legal rights of women. ${ }^{3}$

Mt. Vernon, a farming, embryonic industrial center, located in the fertile rolling hills of central Ohio, was judged to be handsome and "full of life and bustle," but much in need of improvement. Mrs. Bloomer devoted herself to two favorite topics during this year, but she focused her energy on advocating Temperance. She judged it most expedient to concentrate on such after spending her first few nights in the Kenyon House on the town square, with the town rowdies from the corner saloons rousing her from sleep. Decrying the lack of backbone among the village councilmen who had tabled prohibition petitions gathered by women of the community, she recounted Mt. Vernon history of a decade before, lauding the "good people" of the community for raiding the local rumsellers. If only the spirit of the past still prevailed! Her forceful argument for Temperance, as reflected in her editorials ("Shun the Wine Cup," and "The Drunkard's Wife"), led the Bloomers into the company and natural alliance of the reform elements within the community. Eventually their causes were shuttled aside, but for a time the Bloomers fitted into the generally Whig-Republican patrician leadership of first generation Mt. Vernon families. ${ }^{4}$

Mt. Vernon may have had mud streets-providing ample areas for exhibiting Mrs. Bloomer's practical garb ${ }^{5}$ - the filthy taverns south of town may have been breeding grounds for cholera, and the civic architecture may have been little more than early "chickencoop," but the town was politically vital. At least fifteen young men, active in local politics when the 1854 .

${ }^{3}$ Bloomer, Amelia Bloomer, 151, 156. The Lily, January 2, March 1,

${ }^{4}$ The Lily, January 1, 1849, January 2, March 1, 1954.

${ }^{5}$ The term "Bloomers" became a symbol for the early Woman's Rights movement. In reality, this unorthodox garb-a short skirt worn over Turkish, or harem trousers, had first been worn in public by Elizabeth Smith Miller. When Mrs. Bloomer, better known in the New York movement, donned them, the term "Bloomer" was coined. Mrs. Bloomer always credited Mrs. Miller with their innovation. At first Elizabeth Cady Stanton and Susan B. Anthony also wore the costume, but in time all three abandoned it as they judged that it detracted from the serious nature of the movement. 
Bloomers resided there, went on to remarkable careers in state and national service, chief among them being Columbus Delano, Secretary of Interior in 1873 and William Windom, Senator from Minnesota and Secretary of the Treasury in 1880.

Not only were strong personalities abundant in that locale, but 1854 marked the beginning of a massive political realignment nationally, and the machinations were keenly felt in Mt. Vernon. A new political party, a "fusion," was forming, blooded by Temperance advocates, freesoilers, nativists and dissident Democrats. The Nebraska Bill of 1854 provided the Fusion forces with a means to turn a certain statewide Democratic defeat into an utter rout. The amalgamation continued until 1856 when the Republican party, a wildly diverse coalition, controlled by the freesoilers, won the State of Ohio and kept it. Temperance had been the key issue in the State in 1853, followed closely by the anti-Fugitive Slave Law and the antiextension of slavery forces. By 1854, Temperance people, and most other single reform groups, found themselves in second or third places in priority. Even the local county ticket of 1854 relegated Temperance people to lower slots on the "fusion" ticket, as a larger coalition froze out the fragmented special interests. By the end of 1854 the temper of the times blunted the Bloomers' activism and they moved west. ${ }^{6}$

Life in Mt. Vernon in the year of their residency, reconstructed via the three existing newspapers, presents a lively picture. The editors were active participants in the Bloomers' lives and their attitudes color their interpretation. The True Whig, formerly the dominant paper in the county, was losing ground in the party realignment and ceased publication a year later. Edited by A. Banning Norton, scion of a pioneer family, future Texas state senator and federal jurist, the True Whig reflected the individualistic obstinate views of the man "that's all 'unshaven and unshorn'." As a sample of his ob-

${ }^{6}$ Euguene H. Roseboom and Francis P. Weisenberger, A History of Ohio (New York: Prentice Hall, 1969), 165-174, 233-247. A summary of political movements in Mt. Vernon is drawn from an article entitled "Genesis of the Republican Party in Knox County, Ohio," by L. A. Porter, in the hands of the Ohio Historical Society. The Mt. Vernon Democratic Banner, July 11, 18, August 15, 29, September 5, 1854. 
stinancy, Norton went to his grave a decade later faithful to his vow never to shave until Henry Clay was elected President. Clay died in 1852 ! The True Whig was primarily a communityoriented paper, decrying abolitionism, bitterly prejudiced against Negroes, and very mildly advocating Temperance. If the True Whig was not a natural ally of the Bloomers, the "reform sheet," the Ohio State Times, was an outright disappointment. This sickly paper, which on the wings of political fortune would become the most powerful paper in town, was during 1853-1854, edited by a fiercely opinionated and abrasive young man named Thomas Withrow. The Ohio State Times composition and circulation reflected Withrow's lack of acumen. His abrupt departure from the community leaving many unpaid bills, plus his single-minded abolitionism perhaps explains the lack of warmth between the Ohio State Times and the Bloomers.

The Mt. Vernon Democratic Banner was in the hands of flamboyant Irish-born Lecky Harper-a thom in the side of most reformers. Harper was the target of all Temperance people, whom he considered unrelieved fanatics, and his was, it goes without saying, the only paper to carry saloon advertisements. Yet it was the conservative Banner, with its "unwashed" clientele, which gave Amelia Bloomer the fairest hearing. It was Harper who always regarded her as a lady, even to the point of coming to her literary defense against the unseemly editorial attack of a Mansfield (O.) journalist-a gallant gesture not offered by the "reform" and "liberal" press. Although Harper greeted her arrival with light jibes and jests, he was open to serious discussion, frequently on a very high level, on any topic, by the women of the community in his frequently printed "Ladies Department"-a decided improvement over the recipe columns reposing under similar headings in the other papers. Mrs. Bloomer was "glad to see this." It was a welcome break in the wall of ridicule or silence generally levied by political papers. All the woman's rights advocates asked was a fair hearing. It seemed that only Lecky Harper was willing to give it. Harper welcomed Mrs. Bloomer's alliance in supporting his pet projects for civic improvement. But, although he recorded the instances of women in law and 
medical schools, he clearly regarded female suffrage and most other reforms "against the Almighty and the Constitution."

To Norton, Withrow and Harper, and to Mt. Vernon in general, Mrs. Bloomer was a curiosity and a celebrity. In addition to her national crusade and her frequent lecture tours, her presence in Mt. Vernon must have had a local impact. Temperance absorbed her energy, but her style of dress and the woman's rights advocacy implicit in it, constantly colored the Temperance issue and provided shot for the snipers. The editor of the Zanesville (Ohio) Times, whose primary objection was to Temperance, also lacked good manners in his scathing attacks upon her dress. He "was so horrified at our 'boots" and 'pantaloons' that he lost his balance entirely, and went off in a paroxysm of affright." She hoped enough ladies in Zanesville would adopt the costume to send him into shock. The Bloomer dress was also the occasion of a controversy with another female editor, which illustrates the diversity of the feminist movement in this era.

Ella Wentworth, editor of a literary journal in Cincinnati, claimed credit for initiating the employment of women in press work, ignoring the fact that men had begun the trend, and were therefore needed partners in the struggle for woman's rights. She also boasted of her barrier-breaking membership in the Young Men's Mercantile Library Association of Cincinnati. The root of what developed into a lengthy exchange between Ella and Amelia seems to have been Amelia's contention that a journeyman printer, a Miss Foote, had been hired by Ella's brother for the journal, but had been dismissed by the lady solely because she was a bloomerite.

She didn't want her paper or her office to give any countenance to such an innovation. We have a young lady in our

${ }^{7}$ N. N. Hill, Jr. History of Knox County, Ohio (Mt. Vernon, Ohio, 1881) 245-246. A. Banning Norton, History of Knox County, Ohio 17791862 (Columbus, Ohio, 1862), fronticepiece. Ohio State Times, August 29 , September $5,19,26,1854$. Withrow was sued by the Times' owner W. H. Cochran for $\$ 1,000$ debt in 1857 . Withrow was then in his final year as editor of the Janesville (Wisconsin) Free Press. I have been unable to trace him after this period. Republican (Nee Times), January 6, 1857. Democratic Banner, January 17, February 28, March 21, April 4, 11, 18, May 30, August 29, September 19, 26, 1854. The Lily, April 15,1854 . 
office who wears 'draggle skirts' but it never occurred to us that our reputation or that of our office would suffer in consequence.

In later years she and other leading feminists would abandon the costume, fearful that it had developed into a divisive gesture, damaging feminist causes. ${ }^{8}$

The Lily of 1854 seems routine to modern readers because we are so familiar with the arguments and issues that are little changed in our day: woman's place is in the home; St. Paul was a sexist; laws discriminate against married women; woman needs work or she becomes an "insipid drone," prepared only for an "aimless frivolous life," "a mere butterfly existence." After a century the issues and complaints are fundamentally the same. The issue of equal employment and wages raised in 1854 bears witness to this fact.

The slow and bitter assault by women on the "male professions" had begun. For a newspaper woman, the most exciting "new frontier" was in her office. By 1853 women were working as typesetters in some offices (the Syracuse Star, the Geauga Republican) and training as compositor apprentices in the office of the Cincinnati Gazette. In New York, Mrs. Bloomer had been forced to reject pleas for employment of women typesetters because she did not own the press upon which The Lily was produced. With the removal to Mt. Vernon, however, she had her own type and a printer in her office. Female printers she would "gladly" have, but she "must trust to the men" until a woman of sufficient experience "to take the entire charge of making up our paper" could be found. This search was the source of an "extended controversy" between Mrs. Bloomer and Norton, the publisher who remained unidentified in Dexter Bloomer's biographical account. ${ }^{9}$

At twenty-eight, Norton was a stuffy man. He argued for " "established' relations of the sexes," thought that the "true nobility of woman was to keep [to] her own sphere, and to adorn it. . ." with her "pure jewel" of "modesty, which these

${ }^{8}$ The Lily, February 1, March 1, 15, 1854.

${ }^{9}$ Amelia Bloomer, writing in the Western Home Visitor, quoted in Bloomer, Amelia Bloomer, 154; 155. The Lily reported that the Home Circle (?) had employed women printers for four years prior to 1854. The Lily, July 15, 1853, January 2, 16, 1854 . 
coarse agitations seem already to have lost sight of"; he was aghast at "short dresses." Norton's idea of humor ran heavily to puns. Scandalized by the threat of publishers to break a printers' strike in Cincinnati by hiring female labor, he advised them to hire "vidders; for it is said that they have a knowledge of small caps, em-braces, forms, etc. which young misses have not attained."

Yet Norton could concede that "the time is not distant" when certain careers, such as medicine, might be opened to women. But he saw jocularity in the ordination of the Reverend Antoinette Brown: "the end of the world as men knew it; let's switch roles, we'll stay home with the babies for the next six thousand years, and see what they can do . . . ; the male animal had just got notice to quit." Lucy Stone's lecture in the Mt. Vernon Congregational church in mid-April (on the employment of women, the topic of which he did not mention ) earned a nod from Norton, as it was delivered to "a tolerably good audience," but "the beauty so much vaunted of by Brother Brister [a Newark editor] 'warn't thar." Brother Norton relished a good fight. The main round came in April and May, 1854 which proved to be stimulating months for the Bloomers and for the town. Sometime "early in the Spring," Mrs. C. W. Lundy, of New York, was employed by The Lily; soon after, the printers struck the Western Home Visitor.

In the compact business section of Mt. Vernon, such an event must have provided the year's highest excitement. The rivalry, both good natured and solemn, among the papers in town was heightened by their close proximity. The Democratic Banner, which stood editorially against all comers, was located on the first floor of the Woodruff Building, and was capped by the local opera house, a fact which led to jibes about Harper's histrionics. The True Whig, and all the reform presses, had a greater liability. The True Whig, Western Home Visitor, the Ohio State Times and The Lily were housed in the building locally known as "the Kremlin." Harper regaled his readers with oblique comparisons between the reformers and the tyrants who, upon the bloody bodies of the oppressed masses, had built the Russian namesake. This tactic was particularly effective whenever Whig-Republican tax measures were de- 
bated, or when "human liberty" was threatened by a Temperance bill. The rival pressmen enthusiastically ragged one another by cutting down the Democratic "hickory" poles or the Republican "walnut" poles, stringing slogans and bunting across the street, serving as rumor mills for sundry local topics. In such a climate an incident as exciting as a strike evolving out of the question of woman's rights must have been delightful to the onlooker, if a little "keystone kopish."

Predictably the first mention of the female employee or of the strike came in the True Whig, on April 19. After the previous forays, Norton had tried to ignore Mrs. Bloomer, but he found this difficult to do in so exciting an instance: "Out of Sorts! The Printers of Mt. Vernon and the publishers of the Visitor." Norton opposed the women, suggesting that they should do what they were meant to do-darn socks. "However desirous ladies may be of doing Press work, we think they should in this inclination of theirs be restrained." He also supported the dissident printers by the names of Poland and Raguet and their proposed bymonthly, The Filibuster, which lived only in the prospectus which Norton published.

The chief object of this paper, as set forth in the prospectus, is to give an 'opportunity for the free, unbiased discussion of the reform called Woman's Rights.' As its name indicates, it will carry the 'war into Africa,' and we have no doubt will cause a fluttering, if not 'lowering of sails' in the camp of Woman's Rights Advocates, Spiritual Rappings and other humbugs. Look out for the fun.

Mrs. Bloomer, no doubt, thought Norton most ungallant, but she was probably more disappointed in the reaction of the Ohio State Times, which printed the grievances of the male printers, but none of her explanations, and accused her of paying scab wages to under-trained women. Mrs. Bloomer had been a strong advocate of equal pay. Earlier she had written, "If woman does the same work, and does it as well, she is justly entitled to the same compensation that man would receive for the same labor." In time she would deny the allegations of the Ohio State Times. ${ }^{10}$

\footnotetext{
${ }^{10}$ Bloomer, Amelia Bloomer, 175. The Lily, March 15, 1854. Ohio
} State Times, April 25, 1854. True Whig, February 8, March 15, 22, 29. April 5, 19, 26, May 17, 1854. Daily True Whig, November 28, 1853. Poland disappeared from records, but Raguet remained a journeyman 
Lucy Stone had delivered her address on "Woman and Her Employment" two weeks past; it was a bright light for Mrs. Bloomer.

This happened very fortunately in the middle of the excitement about the difficulties in our office, and her words were like soothing oil on the troubled water. It seemed to us as though an over ruling hand had directed her steps hitherward to allay the excitement, to subdue the angry feelings, to plead the cause of woman and proclaim the eternal principles of justice and right.

The April 15th edition of The Lily was printed on the 25th and presented Mrs. Bloomer's account of the tumult in her office, during which The Lily was forced "in contact with a breeze that was impregnated with malice and revenge." The printers left "on account of our having employed a woman to set our type-the men declaring they would not work in the office with, or give instruction to a woman." Faced with this ultimatum, she would not budge, nor would the publishers of the Western Home Visitor, her husband Dexter Bloomer, and Higgins, who declared that they "were pledged to see that she had all the necessary instruction in her business [and] could not submit to such an arbitrary rule on the part of the men in their employ, and so they were all discharged." By the time of publication, on the 25th, women were employed as typesetters in the Western Home Visitor office, and already "the cloud of tobacco smoke [was] being dispelled, so that one can breathe the air without inhaling the effuvia of the poisonous weed, and the filthy puddles on the floor are no longer there to sicken and disgust."

In the next edition of The Lily, Mrs. Bloomer sought to explain the progression of events which had led to the strike. At the outset, The Lily had been typeset by a man employed by the Western Home Visitor. In mid March, Mrs. Lundy, who had three months experience in the East was employed by The Lily. The men in the Western Home Visitor shop knew of Mrs.

printer in Mt. Vernon working for a time for the Republican. In 1857 he quit the Democratic Banner office, after the inevitable personality clash, and set up an equally abortive dissident Democratic paper, the Mt. Vernon National, during the party division over the admission of Kansas under the Lecompton Constitution. Republican, April 27, 1858. June 15, 22, 20, August 17, 1858. Mt. Vernon National, August 19, 1858. 
Bloomer's intention and voiced no dissent. Mrs. Lundy came to The Lily as "an apprentice, on favorable terms, for one year, at the expiration of which time it is understood that she is to receive journeymen's wages for her labor." This was crucial to the printers' dispute, as Mrs. Bloomer had reduced the apprenticeship period that was required for the ordinary apprentice, a teenage boy. She also pledged equal pay with men upon the completion of this training. Mrs. Lundy was to receive all necessary instructions, either from Higgins, a practical printer, or someone in his employ. This had been done by Higgins "cheerfully and faithfully," but the male employees had made it exceedingly uncomfortable for the woman to work with them.

On April 14th, when Higgins and Bloomer were absent, the crisis broke. Mrs. Lundy required advice, and the printers, led by the foreman, refused to give it, and produced a paper, signed by all the printers in the town, pledging that none would aid her. The emotional pitch was heightened when the foreman dared Mrs. Bloomer to find a printer in Ohio who would instruct a woman. After a long conference with the Western Home Visitor's publishers, in which the promise was repeated that the woman would work only on The Lily, the men refused compromise and struck. Mrs. Lundy laboriously set type for the Western Home Visitor, already overdue, and the owners hired three women plus a male journeyman from Columbus, Ohio to instruct them. Within three weeks, the office staff was complete and consisted of four women and three men, working on both papers:

working together peaceably and harmoniously. It does our heart good to see the happy change which had been wrought in the office by this attempt to crush woman's efforts in her own behalf ... Woman's cause is upward and onward, and all the puny efforts that man may make to stop it will be like attempting to blow back the rushing wind with a breath. ${ }^{11}$

With this fine example of Amelia Bloomer's rhetoric, The Lily's account of the strike ends. It had been a triumph, but how enduring?

Snide remarks in the True Whig indicate that the excitement over woman's rights precipitated by this event continued. Commenting on an anti-woman's rights letter in the 
New York Express, which suggested that the Amazons go to Utah or Nebraska, Norton was pleased that

amid the unsexing of the radicals in petticoats, it is gratifying to reflect that the majority of women are opposed to, and entirely discountenance the woman movement. While women may have wrongs, she cannot very much lessen them by bringing odium upon the sex, by the most imprudent, and often the most foolish of measures.

Following the exposition of the facts behind the strike, Mrs. Bloomer paid little written attention to the local community, nor did she again comment upon the strike or personalities involved. Her only local attention in several months was in expressing pleasure that the liquor law was "pretty effectually enforced in Mt. Vernon," although no sellers had yet been arrested, the town was quiet at night.

National causes, however, continued to receive her attention. She attended in June a Temperance Convention in Utica, New York, and then proceeded on a Temperance crusade, installing two Templar Lodges: the Lily Lodge in Greenboro, Indiana, and the Bloomer Lodge in Knighton, Indiana. She waged a continuing war with the editor of the Harper's Weekly on woman's rights. Once again, The Lily encouraged women to seek careers in pressroom employment. She congratulated women printers in defeating a male strike against the Philadelphia Daily Register. She encouraged young women to go west in search of new freedom. An advertisement in the Council Bluffs Bugle for a lady typesetter was particularly pleasing and appealing to Mrs. Bloomer.

One senses a restlessness in the June-July issues of The Lily. A letter from Iowa was printed, lauding the fertile ground for woman's rights and Temperance. On July 15, The Lily announced that Bloomer had sold his interest in the Western Home Visitor to Higgins. Bloomer was gravitating westward, and was off on a scouting expedition. Whether this was due to the lure of the West, dissent between the partners during the strike, or financial pressure, is not known.

While her husband traveled in the West, Mrs. Bloomer engaged in the fall elections in Mt. Vernon. She had supported most of the "reforms" of the day; although hers was a special interest paper, she obliquely supported opposition to the Fugi- 
tive Slave Law and the Nebraska Bill. Now, her understandable miscalculation was in not sensing that the tide for her causes had ebbed. The election issue she emphasized was Temperance. She expressed enthusiasm that the town was far more livable since the election of Temperance men to local offices the past spring. She was, therefore, deeply troubled that the "People's Convention" ignored Temperance candidates in their fall ticket. In a burst of political naivete she wrote, "Surely the Temperance question is of far more importance to the interests of the county and to the state than that of the Missouri Compromise and the Nebraska Bill?” It was not. The political alignment was radically changing. The election of 1854 was the bellwether.

The People's Party was growing, and would by 1854 be dominant in the community. The adherents of the new party were free soilers, abolitionists, Temperance men, Whigs and dissident Democrats. As the regular Democratic party drew the foreign-Catholic vote, and as that vote swelled when the immigrants of 1848 became citizens, the local compaign of 1854 and 1856 reflected the national pattern. It was heavily laced with anti-Catholic, Know Nothing propaganda, fear of the Pope, of the "ignorant foreigner," of non-Anglo Saxon blood, of Catholics voting by priestly order, of Catholics burning the town-all red herrings to bind the conglomeration of Fusion-People's Party into one anti-Democratic faction.

The True Whig and the Ohio State Times ignored the presence of such propaganda in the campaign, and denied the very existence of Know Nothing Lodges, although Norton later admitted holding a statewide Know Nothing office. Irishborn Lecky Harper fought Know Nothingism tooth and nail. Only Bloomer's Western Home Visitor, among the Democratic opposition, admitted that the movement existed and sought to discredit it on grounds of fair play. In this, and the single minded naivete of the Bloomers' commitment to Temperance, they stood alone. "Fusion" swept to victory on the wings of campaign rhetoric, and the Temperance people were left in the eddy, out of the main current. The composition of local politics had changed. A healthy jump in the Irish Catholic population during these years gave fuel to the Know Nothing tac- 
tics of rumor, but the power structure would choose the Freesoil issue as the "cause" for the future Republican party. All other issues faded into muted echoes. ${ }^{12}$

The inevitability of the move west was apparent by September, as The Lily reported the rush of anti-Nebraska Bill and Temperance people to Iowa. Iowa was particularly alluring because it had granted property rights to married women and made them joint guardians of their children. Although invited to "transplant ourselves [and The Lily] to the fertile soil of Iowa," Amelia Bloomer doubted the feasibility because neither the population nor the mail service upon which her subscribers would depend were sufficiently advanced in Iowa to support The Lily. Her husband returned from a trip to Bluff City and Omaha, Nebraska in November. On December 1, The Lily advertised the sale of type, nearly new, by D. C. Bloomer, cryptically promising an announcement regarding The Lily in the next edition. That announcement reported the sale to Mrs. Mary B. Birdsall, ladies' editor of the Indiana Farmer, Richmond, Indiana. Mrs. Bloomer had undertaken a lecture tour to Richmond the previous October at which time she must have arranged for the sale. She intended to remain active as a corresponding editor, and promised "a change, not a Farewell." After six years of publishing The Lily, she was tired, her husband was going west within three months, and "Home and husband being dearer to us than all beside," she would regretfully leave The Lily and follow him to Council Bluff City, now Council Bluffs, and their home on the bluff. ${ }^{13}$

The Bloomers lived in Mt. Vernon one year and five days, not long enough to form deep ties but long enough so that they felt deep regret at leaving many friends in the Templar Lodge, especially William Windom. Her friends invited her to make a farewell lecture at the Congregational Church, and

${ }^{12}$ True Whig, May 3, 24, July 12, 1854. The Lily, March 15, June 1, 15, September 1, 15, October 1, 1854. "People's Convention" was a term used by the new party architects in 1854-56. In the prior year it had been called "Fusion" by its opponents. Now the party flew the banner of the "Peoples' Party."

${ }^{13}$ The Lily, September 1, October 1, November 1, December 1, 15, 1854, January 1, 1855. 
after doing so, Amelia Bloomer removed west. What is the real impact of her sojourn? Certainly her presence in Mt. Vernon is not even remembered now. This writer would judge that her legacy lies in the personal esteem that she and her husband, Dexter, gained while in residence and service to the community, and in Amelia's consciousness-raising of the merit of woman's rights. Several prominent local women subsequently published feminist arguments in the column of the Banner, a fact that attests to her influence. She might not have won equality for women during her stay in Mt. Vernon, but her efforts were part of the history of what has proved to be a significant movement-woman's struggle for equal rights in the economic, political and social structure of America. The Bloomers went west, to new horizons, hoping to find new fields to sow their ideas-that a few flourished and bore fruit in Ohio is but a bonus of the time spent on their way west.

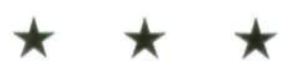

The Little Red Schoolhouse, written and illustrated by Eric Sloan, noted American painter, is an evocative history of early American schools. It describes an era of fond memory and a different-valued way of life. With an appreciation for their rewards and an infinite capacity in delineation, Mr. Sloan writes of and pictures the many aspects of days past when the three Rs really stood for reading, 'riting and religion-the triple-legged foundation upon which our original educational system was built. The large $\left(8^{\prime \prime} \mathrm{x} 11^{\prime \prime}\right)$ size pages and attractive layout of the book make it particularly appealing. It was published by Doubleday and Company, Inc. in 1972 and sells for \$4.95.-Ed. 
Copyright of Annals of Iowa is the property of State of Iowa, by \& through the State Historical Society of Iowa and its content may not be copied or emailed to multiple sites or posted to a listserv without the copyright holder's express written permission. However, users may print, download, or email articles for individual use. 